\begin{tabular}{c} 
Volume and Issues Obtainable at Center for Sustainability Research and Consultancy \\
Journal of Business and Social Review in Emerging Economies \\
ISSN: 2519-089X \& ISSN (E): 2519-0326 \\
Volume 7: Issue 4 December 2021 \\
CSRᄃ \\
Journal homepage: www.publishing.globalcsrc.org/jbsee \\
\hline
\end{tabular}

\title{
China's Development of Gwadar as a Regional Maritime Hub
}

* Rahat Iqbal, PhD, independent researcher in International Relations, Pakistan

Inamullah Jan, is lecturer at Department of Politics and International Relations, International Islamic University, Islamabad, Pakistan

Zafar Iqbal Yousafzai, is Senior Research Associate at SVI, an Islamabad-based think tank, Pakistan

*Corresponding author's email: rahat-iqbal@ hotmail.com

\begin{tabular}{|c|c|}
\hline ARTICLE DETAILS & ABSTRACT \\
\hline $\begin{array}{l}\text { History } \\
\text { Revised format: Nov } 2021 \\
\text { Available Online: Dec } 2021\end{array}$ & $\begin{array}{l}\text { Purpose: This article aims at analyzing China's development } \\
\text { of Gwadar as a maritime hub in the region. Gwadar, after }\end{array}$ \\
\hline $\begin{array}{l}\text { Keywords } \\
\text { China, Gwadar, Maritime } \\
\text { hub, CPEC, Pakistan }\end{array}$ & $\begin{array}{l}\text { Karachi and Bin Qasim Port is the third seaport of Pakistan, } \\
\text { which has a greater impact not only on Pakistan but also on } \\
\text { regions, especially China. Moreover, the paper through light on } \\
\text { the features of CPEC which connects Gwadar with China. }\end{array}$ \\
\hline JEL Classification & $\begin{array}{l}\text { Challenges which Gwadar has to face in the near future are also } \\
\text { analyzed. }\end{array}$ \\
\hline & $\begin{array}{l}\text { Methodology: Qualitative and analytical method is used to } \\
\text { conduct this research. }\end{array}$ \\
\hline & $\begin{array}{l}\text { Findings: The paper concludes that Gwadar is a potential } \\
\text { maritime economic hub in the region. }\end{array}$ \\
\hline & $\begin{array}{l}\text { Implications: Hence, the joint venture will not only bring } \\
\text { multiple benefits to China-Pakistan but also bring opportunities } \\
\text { to the adjacent regions: Central Asia, Middle East and Persian } \\
\text { Gulf. }\end{array}$ \\
\hline OPEN & $\begin{array}{r}\text { (C) } 2021 \text { The authors, under a Creative Commons Attribution, } \\
\text { Non-Commercial } 4.0\end{array}$ \\
\hline
\end{tabular}

Recommended citation: Iqbal, R., Jan, I., and Yousafazai, Z. I. (2021). China's Development of Gwadar as a Regional Maritime Hub. Journal of Business and Social Review in Emerging Economies, 7(4), 1039-1050.

\section{Introduction}

In the post-Cold War era, dynamics of international regime transformed from international politics to international warfare. Economies, in the present-day era are the pivotal factor in International Relations. Countries for vested interest, prefers indirect wars in the form of hybrid warfare, asymmetric warfare or $5^{\text {th }}$ generation warfare's. Similarly, is the situation of Pakistan, due to the importance of its geo-strategic location, it has a vital role to be played in geo-politics. Think thanks in Pakistan, in the present-day era are focusing on the revival of economy and for that CPEC is the matter of concern, of which Gwadar is the backbone.

Gwadar is the third deep-seaport of Pakistan, which was officially inaugurated by President Musharraf in 2007. The land was purchased from Oman at the cost of \$ 3 million in 1958. 
Development of port remained under Port Singapore Authority (PSA) (Ijaz, 2015) for almost five years after its inauguration in 2007 by President Musharraf. Due to its weak performance, this seaport was handed over to Chinese Overseas Port Holding Company (COPHC) in 2013 (PTI, 2018). The development of Gwadar was accelerated with initiation of China Pakistan Economic Corridor (CPEC). Gwadar seaport possesses immense potential of carrying out heavy shipments and transits and has the capacity of bearing more than 20 berths at one time. It can also endure heavy machineries and related stuff. In economic perspectives, it will benefit more than 20 countries of three regions. It also provides the shortest possible route to China for trade to many regions. Gwadar will definitely enhance its cooperation among various countries and states, as it is located at a far distance from the Indian aggression. Additionally, Gwadar has the capacity for carrying out checks and balances for transportation of goods to other areas and also covert operations of India.

It's not only the state that will take benefit from such initiative but it's the people of that particular region who will be at advantage. Baluchistan is considered as the most backward province of the country but with development of Gwadar, it has been transformed into mega city from Small Township. Soon, it will become the hub of large investments due to Gwadar's smooth services provided, which is not borne by major powers of the region. Challenges to its development cannot be ignored at any point. It has the potential to benefit not only countries but regions by providing easy access and routes for trade purposes. However, Gwadar's potential to be a regional maritime hub is challenged by several major initiatives taken by major powers, i) Development of Chabahar, a joint venture of Iran and India, ii) Creation of insurgencies in Baluchistan region iii) Blame games with Pakistan. This paper will identify the potential of Gwadar as a regional maritime hub and also will highlight challenges, which is becoming stumbling block in its development.

\section{China-Pakistan Relations}

China-Pakistan strategic partnership began since the Chinese independence in 1949. The story of the Sino-Pakistan friendship is quite old and beyond explanation. Both of these states had enjoyed cordial relations since establishing diplomatic ties in 1951. Pakistan was the first state to recognize the People's Republic of China in 1950. It also sided with China during the 1960s and 1970s termed as international isolation (Afridi and Bajoria, 2010). China being the key supportive countries towards Pakistan in terms of military, technical and economic. Many analysts opine that the United States (US) strategic partnership with India will ultimately push Pakistan for the closure linkages with China. China-Pakistan Economic Corridor is not only a mega project but taking the bi-lateral ties between the two neighboring countries into a new peak. To bring prosperity and to boost economic growth of both Pakistan and China, CPEC is intended to link Port of Gwadar of southern Pakistan to the Chinese north-western region with the network of railways, roads networks, and pipelines for the transport of gas and oil. CPEC is a significant component in understanding the possible regional trade and connectivity with the SAARC, ASEAN, CAREC and the ECO (Khan 2014).

\section{China's Development of Gwadar}

Chinese ambition of developing Gwadar as a regional maritime hub is the core objective designed in the CPEC initiative. President Xi Jinping suggested for cooperation of "ChinaPakistan Community of Shared Destiny" during his visit in 2015. The proposed notion is based on two particular aspects: i) to enhance collective interest through mutual cooperation and ii) to bolster trust through mutual understanding and cooperation. The Chinese President stated that "Diplomatic Work with Neighboring Countries" is comprised of mutual interest, trust, and cooperation (Lingliang, Z, 2016: 518-523). Moreover, China is prone to build the Special Economic Zone (SEZ) in the less developed part of China named Kashgar. China intends to connect Gwadar port of Pakistan for swift development of the region. In this way, the connected 
route of Kashgar to Gwadar port will provide a convenient access to Arabian sea as well it will help in saving the time of transportation for its quick service of imports from West China to West Asia (Perveen and Khalil 2015). Chinese Ambassador Sun Weidong in Pakistan at a seminar titled "Building Community of Shared Destiny, in the New Era" expressed that Pakistan will be essential ally both at regional and international affairs. Another Chinese analyst and exambassador of China Mr. Zhou Gang also showed concern regarding deepening of bi-lateral ties between China and Pakistan while stating that in order to resist the foreign intervention or forces, for the protection of sovereignty, enhancing security and maintaining stability then one must learn from episodes of uproars of North African and West Asian region.

For the easy access of trade with China, the project of CPEC aims to connect Silk Road Economic Belt (SREB). SREB possess European region to the Central Asian region. This route would help in linking the European or Eurasia region through Central Asia to that of Pakistan via Gwadar. In this way the regions like Eurasia will also be benefit from easy trade with China. Chinese authorities have presented five difference networks including road network, policy exchange, currency circulation, and people to people contacts. (Blanchard and Flint 2017). This project will connect Gwadar with Kashgar in order to boost up the trade links among China, Pakistan, Central Asian states. This is benefiting in two ways i) reducing the time of transportation for trade goods and ii) short route or distance between South China Sea and Arabian Sea. CPEC will be fruitful in having trade with Afghanistan government, strategic projection into Africa and West Asia. The Pakistan's nation also hopes that China will help the country in boosting and progress in the field of gems and agriculture other than energy and communication links.

China and Pakistan will be connected through multiple means through the project of CPEC. This including roads, railways networks, fiber-optic cables, energy projects and functioning or operations of Gwadar deep sea-port. The basic aim of China is to help Pakistan in building highways, motorways and other pending project through CPEC initiative. The project of CPEC is comprised of three phases, short, medium and long-term. To enhance the communication a linkages and transport in the early phases included the construction of orange line Metro train Lahore, along with the upgradation of already existing railway tracks. CPEC is based on the broader scope. It is comprised of construction of new rail and road links and establishment of Special Economic Zones (SEZ) as well making Gwadar operationalized. To re-construct the road links between China and Pakistan is the first and foremost component of the project. Moreover, the project also focuses on changing the street links, the area stretches from Gwadar seaport to Khunjerab pass, the border located in north China. The road such as Karakorum highway will link Pakistan with China through the 15000 feet high. The renovation and re-location of the highways is one of the fundamental components of the road development project in CPEC initiatives. Pakistan areas such as Hasanabdal, Khyber Pakhtunkhwa, and Attabad, etc. will be connected with Chinese region. This will indeed be beneficial to both China and Pakistan (Jawad. F. 2015).

The second important component of CPEC is the enhancement or rehabilitation of the rail links. Since the initial phase of the project Pakistan Prime Minister had given a permission for work start for the advancement of the existed railway tracks of Havelian of Abbottabad District. During the planning phase of CPEC initiative, Chinese railway expert had made a visit to Pakistan for assessment and probability of $\$ 3.5$ billion investment as well for the restoration of tracks stretching from Karachi to Peshawar. In all the project China's ambition of the development of Gawadr deep seaport is essential milestone on which the entire CPEC project is dependent. The entire CPEC initiative is dependent on the operation of Gwadar deep sea route. Therefore, the China's ambition of developing Gwadar will be a milestone achievement only for China and Pakistan but other connected regions as well. The project aimed for the completion of short-term 
project including formation of o Gwadar International Airport, Eastbay Expressway and the breakwater and dredging of breathing channels by 2017. The project also aimed to advance the city with the provision of facilities such as fresh and clean water supply, the building of hospitals, vocational and training institutes comprising of different fields, creating support for nearby industries and export suppliers; and commissioning a coal-fired power plant. The development of Gwadar was early expected as claimed by Chairman Gwadar Port Authority (GPA) Mr. Dostain Khan Jamaldini.

It should be recognized that the development and elimination of switching infrastructure bottlenecks, that is, railways and highways, will facilitate faster movement of items across borders. To make the project successful, Pakistan will play a vital role, despite facing challenges. The initiative of CPEC will also help Pakistan to come out of its economic turmoil and also will be a source of employment for many job-seekers across the country particularly remote areas. CPEC is based on multi-dimensional projects including transportation and energy schemes. It is comprised around $3218 \mathrm{KM}$ route which includes economic free zones, pipelines, highways, railways and infrastructural projects, between Pakistan and China (Shah 2015). CPEC is a component of Chinese mega project of Belt and Road Initiative (BRI) which is composed of Silk Road, Economic Belt, and twenty-first Century Maritime Silk Road. BRI aims to incorporate the twenty-first Century Maritime Silk Road and China Road Economic Belt. The aspiration intends to uplift and to accommodate free trade in economic perspective, to improved integration among countries' markets and well-balanced economic collaboration (Reform 2015).

\section{Characters of CPEC}

The announcement by Xi Jinping in 2014 to invest $\$ 46$ billion under One Belt, One Road initiative was a significant development for various sectors.

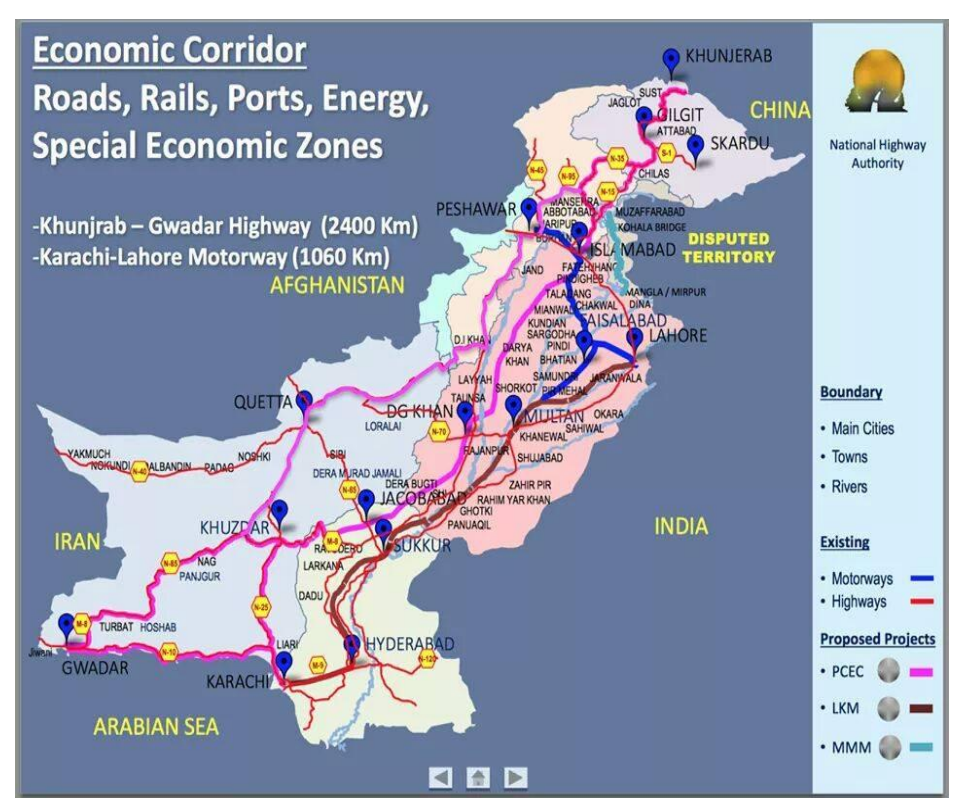

Figure 1: Economic Corridor: Source: https://defence.pk/pdf/threads/genuine-map-of-cpec.372891/

CPEC consists of many projects which will boost up Pakistan's economy. There are different projects which are under development. For infrastructure, there are $\$ 11.8$ billion; $\$ 33.8$ billion for energy sector and @622 million for the Gwadar port development. Moreover, the hydro energy projects have to add 10,400-megawatt energy to the national grid of Pakistan.

Karakoram Route: Karakorum highway connect Pakistan with the western Chinese province Xinjiang. Beside a Chinese firm: China's Production and Construction Corps (PCCC), Frontier Works Organization (FWO) are working to connect all major towns of Gilgit Baltistan with this 
route. Now, the focus of CPEC connectivity is rail routes.

\section{Gwadar Port}

Gwadar seaport will connect China with Arabia Sea. Work is also in progress to enhance Gwadar Port's allotment to 100,000 dead weight tonnage of dry cargo while the capacity of oil tankers will be increased to 200,000 dead weight tonnage.

Energy Sector: For years, Pakistan is in shortage of energy. In order to boost up the energy sector in Pakistan, two third of the CPEC funding will be used. It will add 17,000-megawatt energy to the national grid. Chinese forms are also investing in hydro, coal and solar energy production. A Chinese firm Shanghai Electric is also interested to invest in the energy sector.

\section{Industrial Cooperation}

Industrial sector is one of the key components of CPEC project. Enhancing and developing industrial sector will promote the capacity of smaller and local industries which will ultimately help reduce unemployment in the country. Special Economic Zones are also under development which will provide massive job opportunities.

\section{Agricultural Cooperation}

Pakistan is an agricultural country yet it lacks modern machinery and technology. China is interested to further modernize the agriculture sector of Pakistan. On one hand, Pakistan will get agriculture technology while on the other hand, Pakistan will be able to provide agriculture products to China. Cotton corps productivity is also a main area of cooperation in agriculture. A project is underway that will boost Cotton productivity by the 2030 .

\section{Maritime Hub}

Maritime hub deals with the interstate and intrastate trade linkages through waterways by shipping. Since, the pre-cold war era, states preferred to define various routes to have trade for exchange of goods among countries. Asia, being the largest continent of the world, is blessed with huge markets, which is the mode of attraction for many Western and European states for the purpose of commerce and trade. PSA is set example which is playing its role as global maritime hub. It connected Asia to the world and world to Asia. If we look into the geographical location of Gwadar, it can also become a regional maritime hub, which will not only be beneficial to Pakistan but to many more countries as well. It is only the water routes which connected states and also the only mode of transportation of good and services. Hence, the countries need to make focuses on it as it is playing a vital role not only in business terms but also in the livelihood of nations. The future wars will not be fought for power or expansionism but it will be on water. The various approaches by the major powers of curbing developments with special context to Gwadar is a case in point. Since the division of the Sub-continent, Pakistan was the epic of center due to its geo-strategic location but now with the growing trend it is gaining its momentum as it can also lead to regional maritime hub via Gwadar. Apparently, two maritime hub exists in this world such as PSA on global level and Gwadar soon will start providing its services on regional level.

\section{Pakistan's Maritime Policy, and Interest}

Maritime law or policy governs the sea-based activities such as shipping, seamen and navigation. Under the International law, the area of the sea is divided among states while assigning some coastal lines and nautical miles for the transit routes via sea. Sea, is the main source for transit and transshipments, hence it is essential for every state to strengthen its Maritime security which can easily prevents its exploitation. Pakistan's Maritime policy revolves around Maritime zones, pointing out the territorial waters, Contagious Zones, Continental Shelf, and Exclusive Economic Zone of Pakistan with inclusion of any other area declared by the Federal Government of 
Pakistan (Gazette of Pakistan, 1994). South of Arabian Sea is the coastal line for Pakistan having length of 1046 Kilometer $(\mathrm{km})$. Pakistan's Maritime Policy revolves around means of right, jurisdiction and sovereignty over maritime zones. It includes independent rights of Pakistan to exploit, explore, manage the living and non-living resources, to preserve and many other activities. In economic perspectives such as economic exploration and exploitation as well as safeguarding of unauthorized exploitation of resources of Pakistan Sea and also to keep it safe from pollution (Gazette of Pakistan, 1994).

\section{Maritime and Port Authority (MPA), Singapore}

Like Gwadar, Singapore was based on a small township. Building of the first port container in Tanjong Paga (Singapore) has driven the state to a mega hub from a small port. Currently, it possesses around 600 ports with annual shipping of more than 130,000 ships across the globe. It is connected to 600 ports Lam, 2017) worldwide. Moreover, it also facilitates 63 berths at one time. MPA, Singapore port bears appromatiely120,000 vessels annually. This illustrates that it is the busiest port. After every five minute a ship leaves and arrives at this particular port. Singapore port is one of the busiest ports of the world on the basis of cargo it handles on daily basis and it is a world leading port in container transit for shipments within South East Asia region. Approximately, daily 50,000 containers are transited from container ships. Besides this huge traffic, Singapore port is excellent in its port operations and fast turnovers News Hound, 2014). Observing, port of Gwadar, it has all the capabilities to act as a regional maritime hub as PSA do. Singapore was built a larger city from small township due to the PSA capabilities, along role played by investors. Like Singapore, Gwadar a small township which can emerge as a large mega hub and city with the successful implementation of CPEC.

\section{Gwadar's Geographical Significance}

Gwadar has a greater impact not only on Pakistan but on the region as a whole due to its geography. It is located in the eastern belt of Baluchistan Province (Pakistan). It is the shortest route for connecting China to the warm waters of Arabian Sea. Its coastal belt is around 600 kilometers $(\mathrm{km})$.

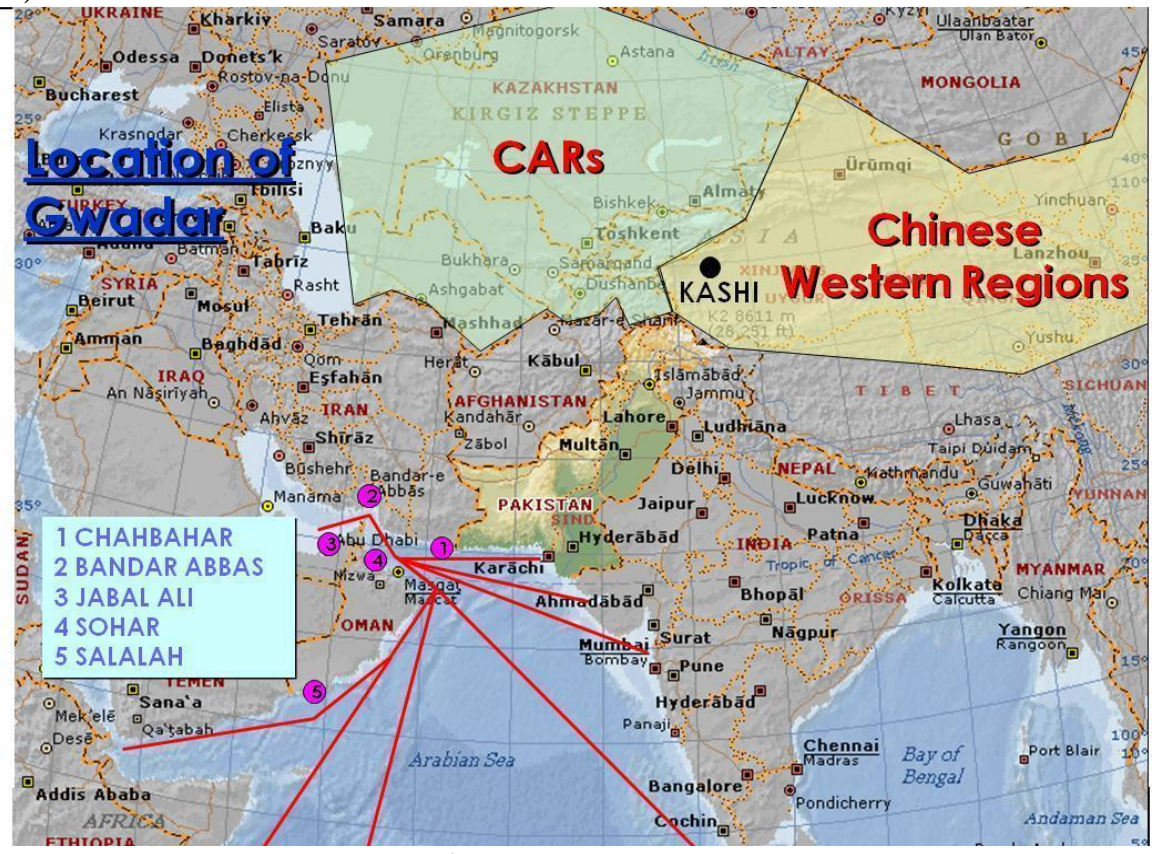

Figure 2: Gwadar's Routes: Source Google Maps.

It lies some 624 nautical miles to the east of the Strait of Hormuz which is the only route of carrying oil tankers to Europe via Persian Gulf (Alamgir, 2011). It is some $460 \mathrm{~km}$ away from Karachi and while having a distance of $120 \mathrm{~km}$ from the border of Iran. It is the third deep seaport which connects the three South Asian, Central Asian and Middle East regions, Afghanistan and 
to some extent Europe, not only through sea but through road as well.

\section{Gwadar's Potential as a Sea Port}

Gwadar seaport is bordering with Iran and is connected to east of Persian Gulf with opposite location to Oman. Additionally, it also connects three regions of South Asia, Central Asian Republics and Middle East. The liberalist's focuses on cooperation among states, in this regard, development of Gwadar's development can lead to cooperation not only on states but regional wise. According to the Chinese Chairman of COPHC Mr. Zhang Baozhong that port of Gwadar has the capability of adjusting more than 70,000 Deadweight Tonnage (DWT) of large vessels (Correspondent 2016). Additionally, Gwadar's seaport has the capacity to bear the birth of more than fourteen ships at one time (Wirsing, 2009: 117-119). After completion of its first phase of three years since its inauguration, the seaport was capable enough for functioning three berths at a time (Anwar, 2011). Gwadar has also the potential of combating covert operation taken by the adversaries, as it is a seaport, which is located at a far distance from India. Due to this leverage, it achieves strategic depth against any attack and can raise early warning against any naval threat. It also holds the ability of successfully providing transshipment facilities with easy access as it is close to the Sea Lines of Communication (SLOCs) (Malik, 2012: 58). Strategic location is the main factor for having the potential of easy transshipment among the regions and states, which Gwadar's possess. For transshipment, Gwadar's seaports have the capability of bearing various loads at one time. It has the capability of transferring goods from door-to-door movements for different spots within minimum time and low cost (Takrim \& Afeef, 2018). It is the second city after Singapore that it provides mega opportunity for neighboring regions of easy trade.

\section{Gwadar's Potential as Economic Hub}

According to liberal school of thought, institution building through economic cooperation is the essential part of international politics. Similarly, development of Gwadar has a significant impact on the regional maritime hub. It is the only deep-sea port, which directly links the regions of Central Asia, South Asia and Middle East. This interconnection among the regions would result in accelerating the trade among three regions, as it is the only seaport, which connects China, not only through sea route but through road as well. Additionally, it is the shortest route for trade to China as compare to water gateways of Mediterranean. Due to the significance of Gwadar, Chinese aspirations have increased for developing linkages with the states of Burma, Bangladesh, Myanmar, South China Sea and Thailand. Invitations to these states were also given for using Gwadar seaport as an alternate during any conflict (Sadiq, 2016: 264-265).

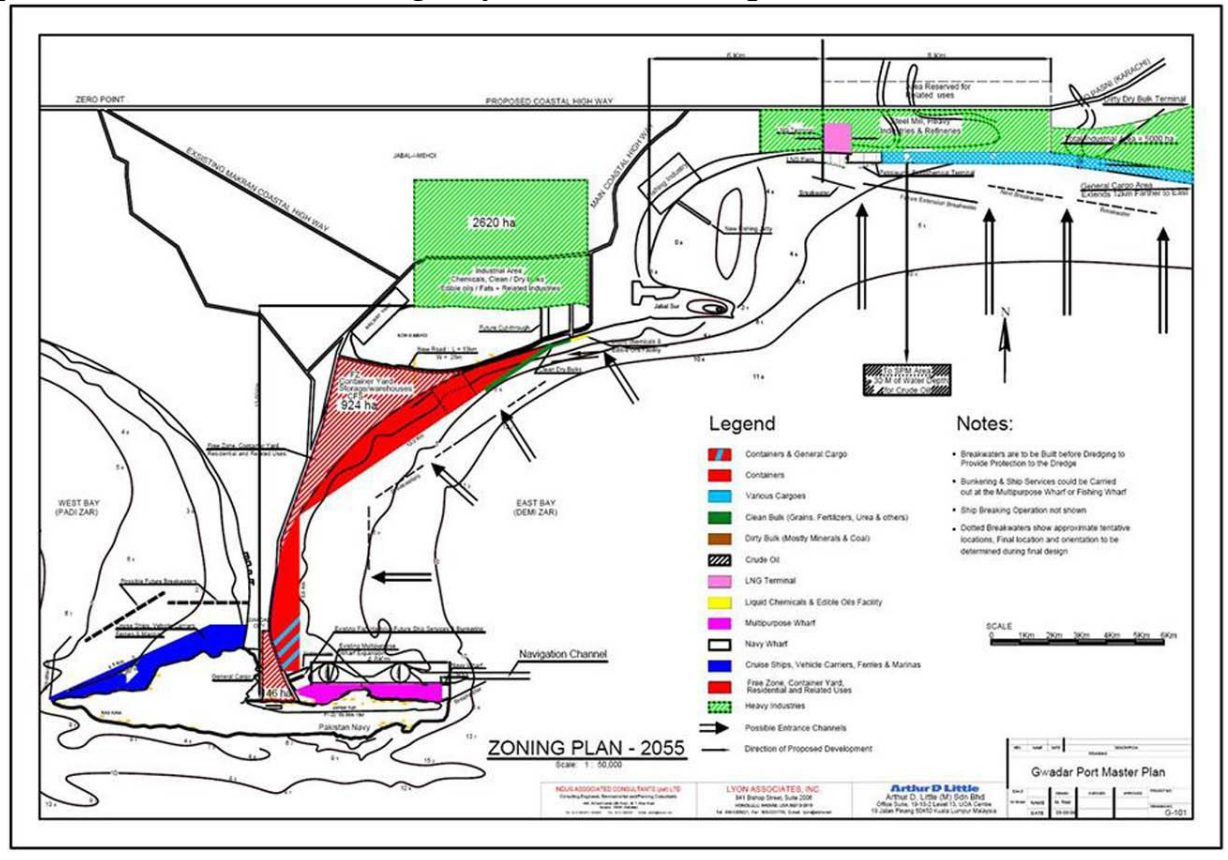


Figure 3: Gwadar's Master Plan: Source: Gwadar Port, Government

According to the theory of liberalism, trade is the source of enhancing cooperation among the states. Therefore, nearly, 20 countries of Middle East, Central Asia, South Asia, and China will be benefitting from this huge project of Gwadar. To be a part of international trade, this seaport will facilitate countries by providing services of transshipment, transit, coastal trade, warehousing and provision of commercial, manufacturing conveniences and industrial units especially to China, Iraq, Iran, Saudi Arabia, Oman, Qatar, Afghanistan, United Arab Emirates (UAE), and Central Asian Republics (CARs) (Alamgir, 2011). As Gwadar is located on the entry to the Persian Gulf through the Strait of Hormuz, it will offer several services to the regional and extraregional key players including European Union, UAE and Persian Gulf. Interestingly, the economic zone through Gwadar seems wide as to offering trade opportunities to Afghanistan and the region of Caspian Sea (Khetran, 2015). Due to the provision of trade and economic via connectivity of regions, trial to curtain development of Gwadar's seaport has brought into action many several times by India as it is a threat to their hegemony. Covert approaches and pressure tactics were the strategies adopted for the implementations of such planning.

\section{Challenges to Gwadar Operations}

We are living in the world of politics; states are continuous process to meet their national interest as prescribed in their policies. If Maritime and Port Authority (MPA) Singapore has the capacity to become the global maritime hub as it connects three continents view sea route. Gwadar, poses serious challenges to the trade among various states with special reference to Asia and Europe through Middle Eastern water ways, which is considered as the global maritime hub. Gwadar has the potential to become the regional maritime hub of the South Asian region, hindering the trade access and trade gains of the major powers. Somehow, the concerned major powers, have adopted some covert approaches as to become hurdle in the development of Gwadar, through various tactics.

\section{Development of Chabahar}

Chababhar is a seaport located in southeastern part of Iran towards Gulf of Oman. It is approximately 72 kilometers away from Gwadar (a deep seaport, develop by Pakistan with the help of China in Province of Baluchistan, Pakistan). It is the only seaport of Iran, which connects, Afghanistan, Central Asia and Iran. It has the capacity of holding the 10 berths at a time. India, on the other hand, in the past several months intended to develop the Chabahar seaport. This initiative was taken when Prime Minister of India Mr. Narendir Modi had made a historic visit to Iran in 2016. India's motive to develop this port (Chabahar seaport) was to bypass Pakistan for having trade access to Afghanistan and Central Asian states. India claims to have a bundle stakes in Afghanistan. India went on a deal with Iran without the consensus of US, which imposed several trade sanctions on Iran due to development of nukes. Moreover, threat of boosting of trade and provision of easily accessible route for trade linkages among the regions have also posed a serious threat of Indian stakes present in Afghanistan. Additionally, India strives for becoming the regional super power will also be abandon with Gwadar's potential of becoming regional maritime hub. To curb the development of Gwadar to become a regional maritime hub, India tended to have deal with Iran. However, since partition, relations both Iran and India have remained in good terms.

"India has already committed significant political and diplomatic resources to the Chabahar project, which it hopes will counter Pakistan's Gwadar port, backed by China" (Scmp, 2018). On the other side, huge investment has been done by India for reconstruction of Afghanistan, which is key ally in the region. Development of Chabahar port would also accelerate the rehabilitation works caused due to wars initiated, while by passing Pakistan. The posture of bridging gap between India and Afghanistan could enable US for rethinking on the decisions of sanction imposed on Iran, due to successful operation of Chabahar port, theoretically curtailing the 
influence of Pakistan and China (Scmp, 2018).

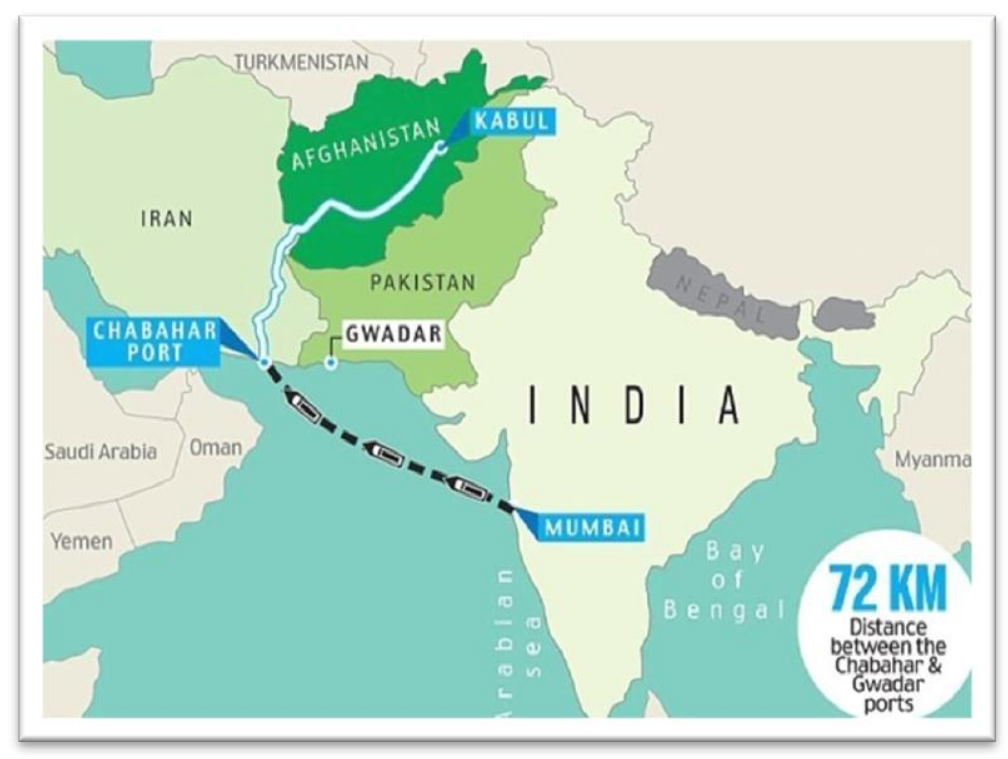

Figure 4: India route to Chabahar, source: Tasnim (Tehran) News Agency

China's initiative of one belt, one road, is also on the watchdog of Iran. Visit of Iran Foreign Minister Mr. Javed Zarif, few months back have enforced Iran to rethinking of joining its venture of CPEC.

\section{China-US Tug of War}

Since, the emergence of the nation state system, the world has been indulged in International politics through International warfare in different dimensions. Since the pre-cold war era, world was in constant move from multi-polarity to uni-polarity, but in the current era, it is vice-versa. Economic interest has remained the constant factor of conflict of interest among or between states. One side it bridges the gap among states but on the other side it is core factor of conflict among states. China- US tug of war in the South Asian region in particular and in the world in general has raised serious concerns, as it is driven force of the conflict in the region.

China's missionary approach is only limited to world affairs only. They had no ideology or system to be spread across the world. China does not claim for any status-quo or power. The agenda to become an economic power is to secure energy, metals and strategic minerals for improving the living standard of the poor generations across

the world and to provide technical assistance and support. The basic objective of China's policy is dominated by economic initiatives, which are not only limited to its borders rather it focuses on global arena through its vertical expansion of soft power.

The US withdrawal from Afghanistan and its shift to Indo-Pacific policy has provided for new challenges to China. Chinese "Nine Dots Line" claim in South China Sea is challenged by US policy in Asia including its influence over Malacca and Sunda Straits and its support to regional countries against Chinese interest. This means a lot to China as its huge trade is through these straits (Bhatti, 2018). In the new strategic policy announced by President Trump in 2017 has clearly declared China and Russia are revision powers due to aggressive response by both of these states. Japan is also enhancing its clout in Indian Ocean region and South Asia as its Free and open Indo Pacific strategy which is mostly on the behest of US. Japan - India partnership is increasing in Asia Africa Growth Corridor initiative. This corridor is estimated at U.S. \$40 Billion including expertise from both the countries in Africa. A vague policy adopted by the major power. U.S strategy to contain China's soft power has started revealing its broad 
repercussions in South Asian region. India is also pursuing its relations with the Gulf States which secured huge investments specially from KSA. India is also reenergizing international North South Transit Corridor (INSTC) Project with Iran and also trying to assess CARs through Chabahar Port of Iran and Afghanistan. In September 2017, Japan and India also signed civil nuclear deal. Recently held India-US-Japan trilateral naval exercises as part of Malabar series and India-Japan maritime exercise (JIMEX) in the Indian Ocean are also a challenge. The US is trying to enhance Indian role in the region, moreover Afghanistan has kept a condition of railroad access to India through Wahga border for joining CPEC.

Hence China's Belt and Road initiative is facing numerous hurdles due to the US grand strategy aiming to contain soft power of China in Indian Ocean and South Asia. The presence of terrorist groups like TTP and Daesh may help create problems in Pak-Afghan border area and Baluchistan which will eventually affect the CPEC projects however, due to successful operations by Pakistan military, majority of these areas on the Pakistani side have been cleared and are secure.

\section{Conflict in Baluchistan}

Incident of 9/11 and the invasion of Afghanistan in 2001 have paved the way for the spread of terrorism in South Asian region, especially in Pakistan. Mainly two provinces in Pakistan including Baluchistan, which has a border Iran, and Khyber Pakhtunkhwa (KP), which has a border with Afghanistan, were severely affected. The several movements in Afghanistan and the call for separation by the Baloch Liberation Movement proven the Indian legacy behind such insurgencies. This was further proven by the arrest of Kulbushna Yadav, an agent of Research and Analysis Wing (RAW) during insurgency in Baluchistan by Pakistan Army. The continuous presence of violence and chaos in Baluchistan will lead to instability, particularly in the province. To target Baluchistan, is to abandon the development of Gwadar, which is soon going to become the regional maritime hub. To pursue such interest, the government of Pakistan claims for foreign intervention including United States (US) and India, in such activities. Jundullah leader during his arrest, claimed for the provision of base in Afghanistan with military equipment by US has endorse the allegations imposed by Pakistan government (Normool, 2018).

\section{Geographical Aspect}

Law and order issues in Pakistan are matter of concern especially for the area like Baluchistan. Gwadar will help in connecting the silk belt from Pakistan to that of Kashgar, via water connection and road. Kashgar is the city of great significance to China. The continuous terrorist activities and insurgency in the region is an alarming situation which needs to be highly addressed. Pakistan defense is making efforts to contain such activities via launching of military operations. To counter such activities a new task force known as Special Security Divisions, which will be comprised of 10000 in armed forces and wings of Frontiers Corps as well as rangers will be assembled for security purposes.

\section{Blame Games}

The stakes of the US and India lies in the Afghanistan, Middle East and Central Asian Republics (CARs). US is having its hegemony while India is striving for becoming the regional superpower. Hence, the development of Gwadar, poses a serious threat to the status quo of both of these states. However, to curtail such expansionism is not an easy task. Neither it can be stopped, nor it can be abandoned. One has to play tactfully. Financial Action Task Force (FATF) during its meeting held in Paris (France)proclaimed to put Pakistan in the grey list for failing in combating terrorism in the country. This was somehow a misunderstanding created by US, to pressurizes other countries for abandoning the infrastructural development in Pakistan including China and Saudi Arabia. 


\section{Conclusion}

Development of Gwadar and the Maritime Silk Route will pace the regional trade as it will have the capacity of obtaining excessive import and exports. Gwadar's leasing to China is the part of One Belt One Road, which is an initiative for connecting China to Europe by land. Gwadar's seaport will enhance cooperation and trade among the states and regions. As said in the theory of Liberalism that one of the ways to reduce conflict is to have focus on developing stronger trade linkages. Hence, Gwadar can be viewed as the source of abolishing the conflict or restraining of war among states due to its regional connectivity and its advantages. There, is no doubt that provision of services through Gwadar will bring prosperity among region but at the same time its development is emerging as a source of conflict due to vested interests of US and India.US under President Trump administration in warming its relations with Indian covering all the required fields, which has helped India in adopting the policy of no talks with Pakistan in the context of cross border terrorism. The US-Indian cooperation is affecting the economic interdependence of Pakistan in many terms due to vested interest of both of these states. To have effective economic regional alliance and making CPEC with context of Gwadar a successive project it's to think on re-opening of talks with India for bilateral issues. Mover, in the current scenario, Pakistan needs to expand its economic ties with countries of Gulf Cooperation Council (GCC). It also needs to enhance its cooperation of trade with countries such as Iran, Turkey and Central Asian States by using the platform of Economic Cooperation Organization (ECO), which will help in reviving the economic status-quo of Pakistan.

\section{References}

Alamgir, M. (September 16, 2011). Strategic importance of Gwadar port for Pakistan. Wordpress. https://muhammadalamgir.wordpress.com/2011/09/16/strategic-importanceof-gwadar-port-for-pakistan/.

Anwar, Z. (2011). Gwadar deep sea port's Emergence as regional trade and transportation hub: prospects and problems. Journal of Political Studies, (1) 2. 45-52.

Ijaz, A. (2015). Significance of Gwadar Port. Islamabad Policy Research Institute, Islamabad. Available at: http://www.ipripak.org/significance-of-gwadar-port/.

Jetley. 'Pakistan's regional and global politics. London-New Delhi, Routledge.

Khan, A. U. (2014). Pak-China Economic Corridor: The hopes and reality. Regional Studies no. 33 (1): 45-63.

Khetran, S. M. (2015). The prospects and potential of Gwadar Port, Institute of Strategic Studies, Islamabad. Also available at http://issi.org.pk/wpcontent/uploads/2015/12/Sherbaz_3435_SS_41_20142015.pdf.

Lam, Y. Y. (2017). Three factors that made Singapore global logistic hub. The World Bank. http://blogs.worldbank.org/transport/three-factors-have-made-singapore-global-logisticshub.

Lengliang, Z. (2016). Conceptual analysis of Belt and Road Initiative: A road towards a regional community of common destiny. Chinese Journal of International Law, 15 (3). 121-137.

Malik, H. Y. (2012). Strategic importance of Gwadar port. Journal of Political Studies, (9) 2: 113-128.

News Hound. (2014). Singapore: A maritime hub, International Institute of Maritime Surveying. UK, Singapore. https://www.iims.org.uk/singapore-maritime-hub/.

Normool, A. N. (2018). "Root causes of conflict in Baluchistan, Pakistan" Brandeis University. Accessed on September 2, 2018 at https://www.beyondintractability.org/library/rootcauses-conflict-baluchistan-pakistan.

Perveen, S and Khalil, J. (2015). Gwadar-Kashgar economic corridor: challenges and imperatives for Pakistan and China. Journal of Political Science. Vol. 22, Issue No 2: 351-366.

PTI. (April 20, 2017). Pakistan's Gwadar's port leased to Chinese company for 40 Years. Indian Express. http://indianexpress.com/article/world/pakistan-gwadar-port-leased-to-chinese- 
company-for-40-years-4621432/.

Sadiq, H. M. (2016). The end of the great game: Was Pakistan the real US target? HMS Books.

Takrim, K \& Afeef, M. (018). Prospects of Gwadar port as a hub port, Journal of Managerial Sciences,X(1).http://www.qurtuba.edu.pk/jms/default_files/JMS/9_1/JMS_January_June2 015_89-99.pdf.

The Gazette of Pakistan. (1994). Extraordinary, Authority. Modified on March $1^{\text {st }}, 2018$, http://www.na.gov.pk/uploads/documents/1329798704_378.pdf.

Wirsing, R. G. (2009). The progress of Détente in India-Pakistan relations. In (eds) Rajeshree. 